to the late Professor Ward. It was at Edwin Smith's suggestion that the Institute organized and obtained international support for the Northern Bantu borderland linguistic field survey, the findings of which are in course of publication.

In his later years, after editing a series of studies on African religion in African Ideas of God (1950), his interest was concentrated again on southern Africa and the epic period of missionary endeavour on which he had built as a young man. $\mathrm{He}$ wrote The Blessed Missionaries (1950), The Life and Times of Daniel Lindley (1950), and Great Lion of Bechuanaland: The Life and Times of Roger Price (1957).

The Institute owes a great debt to the forcefulness and simplicity with which, in its early years, Edwin Smith presented, as he put it, 'the need for an application of scientific method to a solution of the questions arising generally from the contact of Western civilization with African culture and particularly from the attempt to educate Africans on modern lines'. One of the last things he wrote was a characteristically appreciative and constructive review for Africa of Lord Hailey's revised Survey of Africa, which we print in this number.

DARYLL Forde

\title{
RETIREMENT OF THE INSTITUTE'S SECRETARY MRS. B. E. WYAT'T
}

$\mathrm{M}^{\mathrm{R} s}$ RS. WYATT will retire from the secretaryship of the Institute at the end of March 1958. After assisting Sir Hanns Vischer during the later years of the war to keep the Institute in being, she became its Secretary in April 1945, and has since then been intimately associated with its many activities over a period of considerable development since the war. An expanding and increasingly diversified programme of research and publication has continuously increased the amount and complexity of the secretarial activity to which Mrs. Wyatt has, over the years, applied herself with great energy and adaptability and an enthusiasm with which she has always succeeded in inspiring our small staff. As assistant editor of Africa and in her editorial work on the books published by the Institute, she has done far more than 'see the work through the press'. Many whose studies we have published have gladly acknowledged that Mrs. Wyatt has not only relieved them of much of the burden and uncertainty of proof correction, but has kept an eagle eye on grammatical lapses and prolixity, and offered constructive suggestions for improving the presentation. Her practical assistance and sympathetic encouragement will also be gratefully remembered by many holders of Institute fellowships. Her husband, Professor S. H. Hooke, has been invited to join the Department of Divinity in the University College of Ghana for the spring term of 1958 , and the officers have, with the approval of the Council, offered her salaried leave from January to enable her to see for herself something of the life of the continent with which she has been so closely connected on the Institute's behalf. Her many personal friends among the members of the Institute, while greatly regretting that she is no longer immediately available to deal with their requests for information and advice, will, in gratitude for all that she has done for them, wish her a most rewarding visit to West Africa and new satisfactions in what will undoubtedly be an active retirement.

DARYLl Forde 